\title{
PENGARUH PENAMBAHAN LIMBAH TEMPE TERHADAP KARAKTERISTIK NATA DE LERI PADA BERBAGAI KONSENTRASI
}

\author{
Anisa ${ }^{1)}$, Ilah Nurlaelah ${ }^{2)}$, Ina Setiawati ${ }^{3)}$ \\ ${ }^{1}$ Mahasiswa Program Studi Pendidikan Biologi FKIP, Universitas Kuningan \\ Email : an69064@gmail.com \\ ${ }^{2}$ Dosen Program Studi Pendidikan Biologi FKIP, Universitas Kuningan \\ Email : ilah.nurlaelah@uniku.ac.id \\ Email : ina.setiawati@uniku.ac.id
}
APA Citation: Anisa, A., Nurlaelah, I, \& Setiawati, I. (2018). Pengaruh Penambahan Limbah Tempe Terhadap Karakteristik Nata De Leri Pada Berbagai Konsentrasi. Quagga: Jurnal Pendidikan dan Biologi, 10(2), 6-10. doi: 10.25134/quagga.v10i2.1236.

Received: 04-06-2018

Accepted: 27-07-2018

Published: 30-07-2018

\begin{abstract}
Abstrak: Pembuatan nata menggunakan bakteri Acetobacer Xylinum membutuhkan nutrisi salah satunya yaitu nitrogen. Sumber nitrogen dapat diperoleh dari ZA. Namun penggunaan pupuk ZA dalam pembuatan nata menimbulkan polemik dalam masyarakat dikarenakan peruntukannya yang tidak dikhususkan untuk makanan. Oleh karena itu dalam penelitian ini menggantikan peran ZA dalam proses pembuatan nata. Pada umumnya bahan pembuatan nata digunakan air kelapa namun pada penelitian ini menggunakan air leri. Penelitian ini bertujuan mengetahui pengaruh limbah tempe dengan berbagai formulasi terhadap karakteristik nata de leri. Metode penelitian ini menggunakan Rancangan Acak Lengkap (RAL) dengan satu faktor formulasi air rendaman kacang kedelai yaitu 124,4 ml, 129,4 ml, 134,4 ml, 139,4 ml, 144,4 ml, 149,4 ml dan 154,4 ml. Perbandingan air dan beras ketan yaitu $2: 1$. Berdasarkan hasil analisis RA, limbah tempe berpengaruh terhadap ketebalan nata dengan formulasi terbaik yaitu pada formulasi 7 dengan nilai 154,4 ml. Berdasarkan uji Freadman panelis menyukai rasa, warna, aroma dan tekstur nata de leri.
\end{abstract}

Kata Kunci: Limbah tempe, Karakteristik Nata de Leri

\begin{abstract}
Nata de Leri is producted-by Acetobacter xylinum that requires nitrogen. The source of nitrogen can be obtained from ZA. However, the use of ZA fertilizer in making nata raises a polemic in the community due to its allocation which is not devoted to food. Therefore in this research replaces the role of ZA in the process of making nata. In general, nata is producted using coconut water, but in this study using water leri. This study aims to determine the effect of tempe waste with various formulations on the characteristics of nata de leri. This research method used Completely Randomized Design (RAL) with one factor of soybean water soil formulation that is 124,4 ml, 129,4 ml, 134,4 ml, 139,4 ml, 144,4 ml, 149,4 ml and 154, $4 \mathrm{ml}$. The ratio of water and sticky rice is 2:1. Based on RAL analysis Fcount (3.00) > Ftable (2.66) so that tempe waste has an effect on nata thickness with the best formulation that is in formulation 7 with value 154,4 ml. Based on the Freadman test resulted the calculation of $x^{2}$ count $>x^{2}$ table, where all panelists liked the taste, color, aroma and texture of nata de leri.
\end{abstract}

Keywords: Waste of tempe, Carakteristic Nata de Leri

\section{PENDAHULUAN}

Menurut Friamita (2013) di Kabupaten Kuningan pada tahun 2012, terdapat 25 unit industri kecil tape ketan yang tersebar di beberapa kecamatan. Dengan keberadaan industry tape yang banyak ini tentunya akan menimbulkan permasalahan baru yaitu sebagian besar dari pabrik tape ketan tersebut tidak ada bagian khusus menangani limbahnya terutama limbah dari cucian air beras ketannya, akibatnya jika musim kemarau limbah cucian beras ketan akan tergenang dan akan menimbulkan bau yang kurang sedap. Air cucian beras yang dibuang percuma ternyata masih memiliki kandungan karbohidrat, protein serta vitamin B1 yang banyak terdapat pada paricarpus dan aleuron yang ikut terkikis. Biasanya pemanfaatannya hanya digunakan sebagai pupuk organik bagi tanaman dan media pertumbuhan bakteri mengingat kandungan karbohidrat dan vitaminnya. Menurut Fitriah (2007) kandungan karbohidrat dan zat-zat lain didalam air cucian beras cukup besar sehingga berpotensi sebagai substrat untuk pembentukan selulosa (nata).

Pada produk pembuatan nata dibutuhkan ZA (Zwavelzuur Ammoniac) sebagai sumber nitrogen untuk nutrisi bagi bakteri Acetobacter xylinum, namun penggunaan $\mathrm{ZA}$ tentu harus 
diawasi dengan ketat karena digunakan untuk campuran makanan, terutama konsentrasi ZA yang ditambahkan ke dalam makanan. ZA yang digunakan juga merupakan ZA khusus untuk makanan. Sangat dikhawatirkan penggunaan ZA secara asal-asalan akan mengganggu kesehatan karena ZA ini diperuntukan untuk tanaman sehingga perlu sumber nitrogen alternatif untuk pengganti ZA yang berasal dari alam, salah satunya yaitu dengan penambahan limbah tempe. Menurut Sudarsih (2009) air limbah rendaman kedelai masih mengandung bahan terlarut setelah melewati proses perebusan dan perendaman kedelai, salah satunya adalah nitrogen.

Penelitian ini mengkaji tentang ketebalan nata de leri dengan penambahan limbah tempe dan pendapat masyarakat mengenai yaitu sifat fisik nata yaitu rasa, warna, tekstur dan aroma.

\section{METODOLOGI PENELITIAN}

Penelitian ini dilaksanakan di Laboratorium Biologi, Kampus 1 Fakultas Keguruan dan Ilmu Pendidikan Universitas Kuningan yang bertempat di Jl. Cut Nyak Dien No. 36A Cijoho Kuningan. Bahan-bahan yang digunakan dalam percobaan ini adalah air leri sebanyak 1 liter, starter nata yaitu Acetobacter xylinum sebanyak $50 \mathrm{ml}$. Sumber nitrogen yang digunakan yaitu untuk kontrol menggunakan ZA sebanyak 5 gram dan untuk eksperimen menggunakan limbah tempe. Sebagai sumber karbon digunakan gula pasir sebanyak 10 gram dan asam asetat glasial sebanyak $20 \mathrm{ml}$ untuk mengatur $\mathrm{pH}$ menjadi 4,5 digunakan hanya untuk kontrol sementara untuk yang eksperimen tidak ditambahkan asam cuka karena $\mathrm{pH}$ sudah 4,5 .

Alat-alat yang digunakan dalam percobaan adalah panci, sendok sayur, sendok makan, saringan, kompor, baskom plastik, loyang plastik dengan tinggi minimum $5 \mathrm{~cm}$, karet gelang, kertas koran, dan $\mathrm{pH}$ meter.

Metode penelitian yang digunakan adalah eksperimen laboratorium dengan Rancangan Acak Lengkap yang terdiri dari 6 perlakuan dan 3 ulangan. Adapun perlakuannya sebagai berikut (Tabel 1):
Tabel 1. Formulasi perlakuan penelitian

\begin{tabular}{|c|c|c|}
\hline Perlakuan & \multicolumn{2}{|c|}{ Formulasi } \\
\hline Penelitian & Air & Limbah Tempe \\
\hline A & 1 liter limbah air leri & $124,4 \mathrm{ml}$ limbah tempe \\
\hline B & 1 liter limbah air leri & $129,4 \mathrm{ml}$ limbah tempe \\
\hline $\mathrm{C}$ & 1 liter limbah air leri & $134,4 \mathrm{ml}$ limbah tempe \\
\hline D & 1 liter limbah air leri & $139,4 \mathrm{ml}$ limbah tempe \\
\hline E & 1 liter limbah air leri & $144,4 \mathrm{ml}$ limbah tempe \\
\hline $\mathrm{F}$ & 1 liter limbah air leri & $149,4 \mathrm{ml}$ limbah tempe \\
\hline G & 1 liter limbah air leri & $154,4 \mathrm{ml}$ limbah tempe \\
\hline K & 1 liter limbah air leri & 5 gram ZA \\
\hline
\end{tabular}

Karakteristik yang akan diukur adalah sebagai berikut ketebalan, rasa, warna, tekstur dan aroma nata de leri.

\section{HASIL DAN PEMBAHASAN \\ Ketebalan Nata de Leri}

Ketebalan nata yang dihasilkan berbagai perlakuan pada penelitian ini berkisar antara 0.2 $\mathrm{cm}$ hingga $0,53 \mathrm{~cm}$. (Gambar 1).

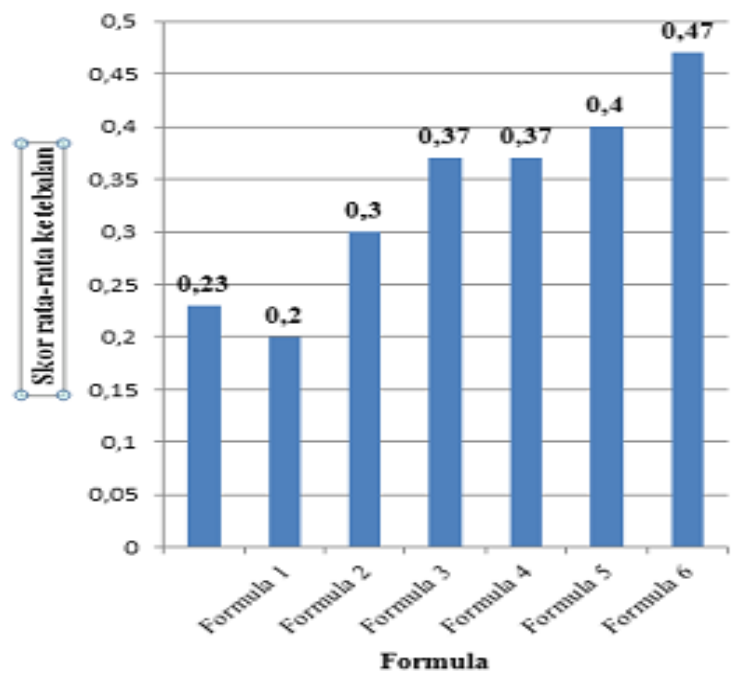

Gambar 1. Rata-rata ketebalan nata de Leri

Berdasarkan hasil analisis RAL $F$ hitung $(3,00)>$ F tabel $(2,66)$ sehingga limbah tempe berpengaruh terhadap ketebalan nata dengan ormulasi terbaik yaitu pada formulasi 7 dengan nilai $154,4 \mathrm{ml}$.

Secara teoritis ketebalan nata tergantung aktivitas dari bakteri Acetobacter xylinum dalam merombak sukrosa menjadi selulosa (lviani, 2006). Ketersediaan selulosa turut berpengaruh terhadap ketebalan nata. Selulosa yang dihasilkan akan membentuk lapisan-lapisan selulosa kemudian lapisan-lapisan selulosa akan membentuk monomer-monomer dan selanjutnya 
akan membentuk polimer (Hamad, 2013). Hal ini yang menyebabkan kerapatan sel dalam medium meningkat sehingga ketebalan nata akan meningkat (Hermawan, 2004).

Menurut Engelstad, (1997) kandungan nitrogen pada ZA sekitar $20-21 \%$, sedangkan kandungan nitrogen pada limbah tempe sekitar 1,5\% ( Salamah et all, 2009). Penggunaan pasokan nitrogen anorganik mampu mempercepat pembentukan nata dan berpengaruh terhadap ketebalan nata (Misgiarta, 2013). Menurut Intan,et all. (2010) jumlah pasokan nutrisi berupa $\mathrm{C}$ dan $\mathrm{N}$ yang berbeda dapat mempengaruhi ketebalan nata yang dihasilkan . Ketersediaan unsur $\mathrm{C}$ dan $\mathrm{N}$ sangat berpengaruh dalam pembentukan nata seperti ketebalan yang dihasilkan (Imam, 2012). Hal ini menunjukkan bahwa jumlah nitrogen memberikan kontribusi terhadap jumlah selulosa dalam layer nata yang dihasilkan. Semakin banyak jumlah selulosa yang terbentuk maka ketebalan nata akan meningkat.

\section{Rasa}

Berdasarkan uji organoleptik terhadap rasa nata yang dihasilkan pada berbagai perlakuan dalam penelitian ini berkisar antara 3,1 hingga 5,58. (Gambar 2).

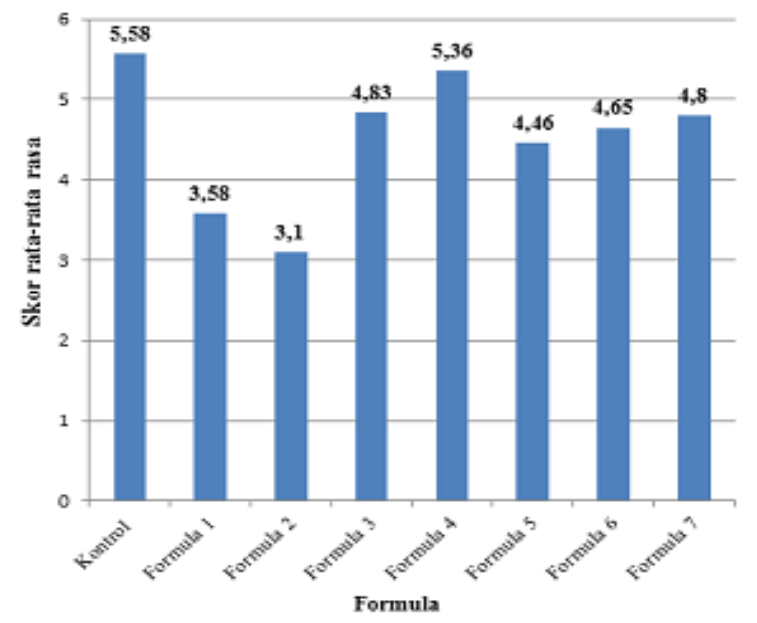

Gambar 2. Skor rata-rata penilaianpenelis terhadap rasa nata de Leri

Rasa nata de Leri berdasarkankesukaan panelis pada penelitian ini adalah rasa nata yang netral. Rasa netral ini timbul selama proses perendaman dan pemasakan, dalam proses terjadi peristiwa osmosis sehingga rasa yang timbul hampir sama. Kemungkinan lain diduga rasa nata yang sebenarnya hambar. Setelah proses perendaman dan pemasakan dengan air gula, rasa nata menjadi manis. Rasa asam yang biasanya timbul pada nata karena adanya kandungan asam cuka dalam nata. Asam cuka yang terkandung dalam nata merupakan hasil sampingan dari fermentasi (Kusharyati, 2016). Pada proses pembuatan nata de Leri dengan penambahan limbah tempe tidak ditambahkan cuka, karena air rendaman kacang kedelai $\mathrm{pH} 4$ media yang cukup asam untuk perumbuhan bakteri.

Tekstur

Berdasarkan uji organoleptik terhadap tekstur nata yang dihasilkan pada penelitian ini berkisar antara 2,77 hingga 5,96. (Gambar 3).

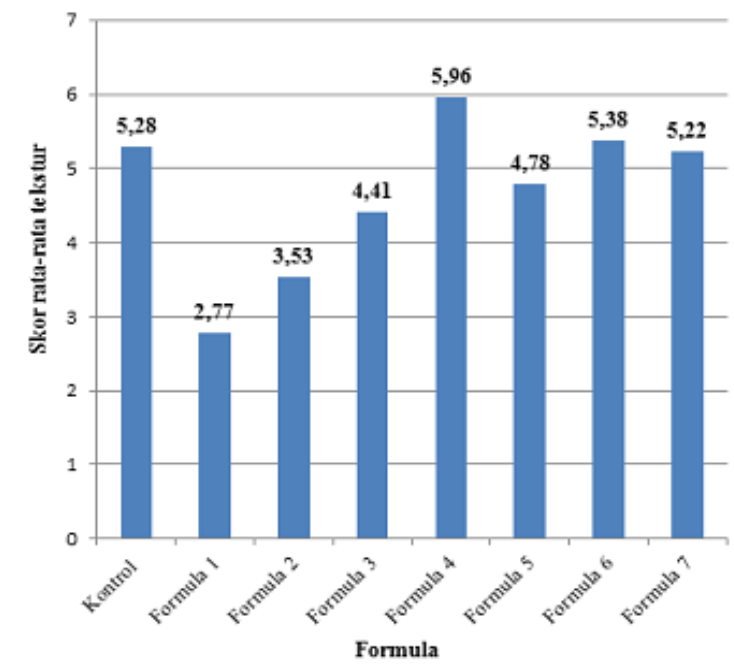

Gambar 3. Skor rata-rata penilaianpanelis terhadap tekstur nata de Leri

Tekstur nata de Leri menurut kesukaan panelis umumnya menyukai nata yang mudah digigit dan dikunyah ketika dikonsumsi. Tekstur yang baik untuk nata adalah kenyal dan tidak keras. Pada gambar 3 menunjukan nata de Leri yang dihasilkan dengan formulasi 4 (limbah tempe sebanyak 134,4 ml) lebih disukai panelis karena tingkat kekenyalannya lebih pas, tidak terlalu keras dan juga tidak terlalu lembek dimana kandungan air dalam nata sesuai takaran.

Menurut Nisa, et all. (2001) kekerasan tekstur berkaitan erat dengan kerapatan jaringan selulosa. Konsentrasi gula yang terlalu banyak atau terlalu sedikit diduga dapat menghambat aktivitas Acetobacter xylinum dalam membentuk selulosa. Selain itu, nilai tekstur juga dipengaruhi oleh kadar air. Hal ini diperkuat oleh Rahman (2004) bahwa struktur kimia dan fisik merupakan efek dari susunan air yang terserap dan berpengaruh besar terhadap tekstur, nilai tekstur dipengaruhi oleh kandungan air pada produk pangan.

\section{Warna}


Berdasarkan uji organoleptik terhadap warna nata yang dihasilkan pada penelitian ini berkisar antara 3,18 hingga 5,36. (Gambar 4).

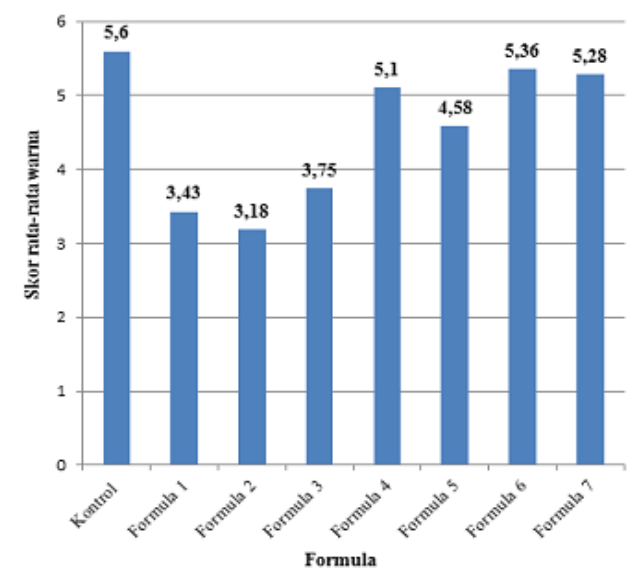

Gambar 4. Skor rata-rata penilaianpanelis terhadap warna nata de Leri

Warna nata de Leri ditentukan dengan kriteria sebagai berikut 1.kusam bercak hitam, 2 . putih bercak hitam, 3. putih bersih. Warna nata yang diamati adalah derajat putih atau kecerahan nata melalui penglihatan subjektif. Warna nata juga dipengaruhi oleh beberapa faktor yaitu adanya penambahan ammonium sulfat. Penambahan ammonium sulfat akan warna nata yang sangat berbeda dengan tanpa penambahan ammonium sulfat. Semakin tinggi kadar ammonium sulfat yang ditambahkan, maka warna nata akan semakin kuning. Hal ini diduga ion-ion hidrolisa ammonium sulfat bereaksi dengan gula atau komponen lain pada air kelapa dan salah satu hasilnya memberikan warna yang lebih gelap. Warna nata juga dipengaruhi oleh media yang digunakan.

Aroma

Berdasarkan uji organoleptik terhadap aroma nata yang dihasilkan pada penelitian ini berkisar antara 3,55 hingga 6,67 (Gambar 5).

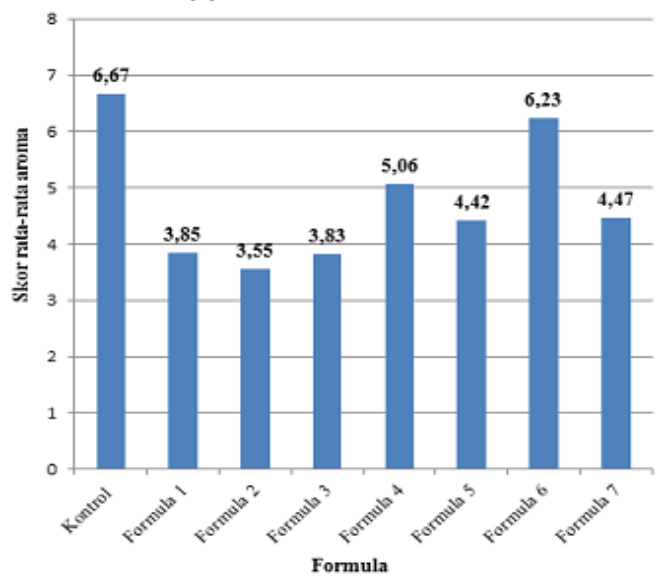

Gambar 5. Skor rata-rata penilaian aroma nata de Leri

Bau asam yang sudah tidak tercium ini karena proses pemanenan dilakukan secara baik. Pada tahap pemanenan nata, lapisan nata yang telah diperoleh dicuci hingga bersih dengan menggunakan air. Tujuan dari pencuciannata ini adalah menghilangkan endapan sisa fermentasi dan mengurangi bau asam yang masih melekat pada nata kemudian setelah direndam 3 hari dan setiap harinya air rendaman diganti. Tujuan dari perendaman nata ini adalah untuk menghilangkan asam asetat yang terbentuk selama fermentasi. Setelah 3 hari direndam nata kemudian direbus hingga mendidih selam 15 menit. Tujuan perebusan adalah untuk membunuh bakteri Acetobacter xilinum, sehingga nata aman untuk dikonsumsi. Hilangnya bau asam pada nata karena tahap pencucian dan penggantian air rendaman dilakukan secara sempurna.

\section{SIMPULAN}

Formulasi terbaik pemberian limbah tempe untuk ketebalan nata de Leri adalah sebesar 154,4 ml (formula 7). Kesukaan panelis terhadap produk nata de Leri berdasarkan warna dengan penambahan limbah tempe 149,4 $\mathrm{ml}$ (formula 6), tekstur dengan penambahan limbah tempe 139,4 $\mathrm{ml}$ (formula 4), rasa dengan penambahan limbah tempe 149,4 $\mathrm{ml}$ ( formula 4) dan aroma dengan penambahan limbah tempe 149,4 $\mathrm{ml}$ (formula 6).

\section{REFERENSI}

Fitriah, L. 2007. Pemanfaatan Air Cucian Beras sebagai Bahan Pembuatan Nata. Seminar Kimia. Fakultas FMIPA Ilmu Keguruan dan Pendidikan : Mataram

Friamita, M. 2013. Eksistensi Home Industri Tape Ketan di Desa Tarikolot Kecamatan Cibeureum Kabupaten Kuningan. Jurnal Antologi Pendidikan Geografi Vol.1(3). Universitas Pendidikan Indonesia. Bandung. (Online). Tersedia : http://repository.upi.edu/475. Diakses 30 $\underline{\text { Januari } 2017}$

Sundarsih dan Kurniaty, Y. 2009. Pengaruh Waktu dan Suhu Perendaman Kedelai pada Tingkat Kesempurnaan Ekstraksi 
Quagga: Jurnal Pendidikan dan Biologi

Volume 10, Nomor 2, Juli 2018

Protein Kedelai dalam Proses Pembuatan Tahu. Makalah Penelitian. (Online). Tersedia http://eprints.undip.ac.id. Diakses 31 Januari 2017

Nisa, F.C., R.H. Hani., T. Wastono., B. Baskoro dan Moestijanto. 2001. Produksi Nata Dari Limbah Cair Tahu (Whey) : Kajian Penambahan Sukrosa Dan Ekstrak Kecambah. Jurnal Teknologi Pertanian. 2: $74-78$.

Rahman. 2004. Pengantar Teknologi Fermentasi. Jakarta : Arcan.

Salamah, Z., Wahyuni, ST, Utami, LB. 2009. Kultivar Kencana. "Pemanfaatan Limbah Cair Industri Tempe Untuk
p-ISSN 1907-3089, e-ISSN2651-5869

https://journal.uniku.ac.id/index.php/quagga

Meningkatkan Pertumbuhan Tanaman Kangkun Darat (Ipomea reptans, poir)" . 